\title{
Pengaruh Pemberian Ekstrak Etanol Daun Lakum (Cayratia trifolia L.) dan Buah Kersen (Muntingia calabura L.) terhadap Bobot Tubuh dan Bobot Lemak Abdominal Rattus norvegicus L. Strain Wistar Jantan Hiperlipidemia
}

\section{The Effect of Giving Ethanol Extract of Lakum (Cayratia trifolia L.) Leaves and Jamaican Cherry (Muntingia calabura L. ) on Body Weight and Abdominal Fat Weight of Hyperlipidemia Male Rattus norvegicus L Wistar Strain)}

\author{
Raditya Setiawan $^{1}$, Tyas Rini Saraswati ${ }^{2 *}$, dan Silvana Tana ${ }^{2}$ \\ ${ }^{1}$ Program Studi Biologi, Fakultas Sains dan Matematika, Universitas Diponegoro \\ ${ }^{2}$ Departemen Biologi, Fakultas Sains dan Matematika, Universitas Diponegoro \\ *Email: tyasrinis63@gmail.com
}

Diterima 17 September 2019 / Disetujui 5 Februari 2020

\begin{abstract}
ABSTRAK
Daun lakum (Cayratia trifolia) dan buah kersen (Muntingia calabura) mengandung senyawa flavonoid, terpenoid, steroid dan kaya akan antioksidan. Beberapa senyawa antioksidan seperti squalene, nimbidin dan saponin berpotensi meningkatkan metabolisme HDL dalam tubuh sehingga dapat mengurangi timbunan lemak tubuh. Penelitian ini bertujuan untuk mengetahui perbedaan bobot badan dan bobot lemak abdominal tikus putih (Rattus norvegicus) strain wistar jantan hiperlipidemia setelah pemberian jus buah kersen dan ekstrak etanol daun lakum. Penelitian menggunakan Rancangan Acak Lengkap (RAL) yang teridiri atas 5 perlakuan dengan 4 kali ulangan, yaitu kelompok kontrol, kelompok pakan hiperlipid positif, kelompok pemberian pakan jus kersen, kelompok pemberian pakan ekstrak lakum dan kelompok pemberian simvastatin. Pakan hiperlipid diberikan selama enam minggu, dimulai dari tikus umur tiga bulan. Pengukuran variable bobot badan diukur tiap minggu dan bobot lemak abdominal di akhir penelitian. Data dianalisis dengan Analysis of Variance (ANOVA) yang dilanjutkan dengan Uji Duncan pada taraf kepercayaan 95\%. Hasil penelitian menunjukan bahwa pemberian tambahan jus buah kersen dan ekstrak etanol daun lakum memberikan pengaruh yang signifikan pada bobot badan dan bobot lemak abdominal $(p<0,05)$ Penelitian ini dapat disimpulkan bahwa pemberian jus buah kersen dan ekstrak etanol daun lakum pada tikus putih jantan hiperlipidemia tidak berpotensi menurunkan bobot badan, namun berpotensi menurunkan bobot lemak abdominal.
\end{abstract}

Kata kunci : Cayratia trifolia, Muntingia calabura, antioksidan, bobot badan, bobot lemak abdominal

\begin{abstract}
Lakum leaves (Cayratia trifolia) and Jamaican cherry (Muntingia calabura) contain flavonoids, terpenoids, and steroids are rich in antioxidants. Some antioxidants compounds such as squalene, nimbidin and saponin are potential to increase the metabolism of HDL in the body so that it can reduce the body's fat. The aim of this study is to determine the differences in body weight and abdominal fat weight in hyperlipidemic white rats (Rattus norvegicus) and the treatment group. This study used a Completely Randomized Design (CRD) consisting of 5 treatments with 4 replications, namely the control group, the positive hyperlipid group, the Jamaican cherry addition group, the addition group of the lakum extract and the simvastatin enhancement group. Hyperlipid feed is given for six weeks, starting with three months aged. Variable measurements are measured every week and at end of the study. The data were analyzed by Analysis of Variance (ANOVA) followed by Duncan Test at 95 confidence level. The results showed that the addition of Jamaican cherry juice and ethanol extract of lakum leaves had a significant effect on body weight and abdominal fat weight $(\mathrm{p}$ $<0.05$ ). Both treatments were significantly different from the positive hyperlipid treatment which had an average body weight of 251,98 $\mathrm{g}$ and 6.22 fat weight as well as the treatment of simvastatin that had an average body weight of $208.55 \mathrm{~g}$ and a weight of fat of $1.75 \mathrm{~g}$. This research can prove that Jamaican cherry
\end{abstract}


fruit juice and ethanol extract of lakum leaves can't reduce body weight, but prevent excess body weight in male white stomach hyperlipidemia.

Keywords : Cayratia trifolia, Muntingia calabura,, antioxidants, body weight, abdominal fat weight

\section{PENDAHULUAN}

Di Indonesia, obesitas merupakan salah satu permasalahan gizi. Berdasarkan Laporan Riset Kesehatan Dasar (Riskesdas) pada tahun 2013, prevalensi obesitas pada penduduk berusia $\geq 18$ tahun berdasarkan Indeks Massa Tubuh (IMT) adalah 15,4\%. Prevalensi penduduk laki-laki dewasa obesitas pada tahun 2013 sebanyak 19,7\% lebih tinggi dari tahun 2007 (13,9\%) dan tahun 2010 (7,8\%). Pada tahun 2013, prevalensi obesitas perempuan dewasa ( $\geq 18$ tahun) $32,9 \%$ naik $18,1 \%$ dari tahun 2007 (13,9\%) dan 17,5\% dari tahun 2010 $(15,5 \%)$. Obesitas erat kaitannya dengan akumulasi lemak tubuh. Obesitas diartikan sebagai peningkatan berat badan di atas $20 \%$ dari batas normal (Guyton, 1997). Penumpukan lemak dalam tubuh terjadi karena energi yang disimpan lebih besar daripada energi yang dilepas, energi tersebut di simpan di jaringan adiposa dalam bentuk trigliserida Simpanan trigliserida berasal dari konsumsi pakan yang banyak mengandung karbohidrat berlebih kemudian diubah menjadi trigliserida (Rolfes et al., 2009). Kadar lemak berlebih dalam tubuh akan disimpan pada jaringan ekstrahepatik atau jaringan adiposa dalam bentuk trigliserida. Pada individu obesitas, kadar lemak yang berlebihan akan memicu penumpukan lemak pada jaringan adiposa, sehingga terbentuk jaringan adiposa yang memiliki volume lebih besar dibandingkan jaringan adiposa pada individu nonobesitas. Volume jaringan adiposa yang melebihi kemampuan penyokong jaringan ikat tubuh, ditambah dengan pengaruh gravitasi, akan menyebabkan peregangan permukaan kulit jaringan adiposa sehingga membentuk lipatan kulit yang tebal di beberapa bagian seperti perut, paha, lengan, dan pinggang (Hazleman et al. 2004).

Indonesia memiliki banyak tanaman potensial untuk pengembangan obat-obatan dari alam, diantaranya terdapat dua jenis tanaman yang berpotensi mengatasi penyakit hipertrigliseridemia yaitu buah kersen (Muntingia calabura L.) dan daun tanaman lakum (Cayratia trifolia (L.) Domin.). Buah kersen (Muntingia calabura L.) dan daun lakum (Cayratia trifolia (L.) Domin) mengandung senyawa flavonoid, terpenoid, dan steroid yang dapat berperan sebagai antioksidan dan memiliki sifat hepatoprotektif (Kumar, 2011). Buah kersen dan daun lakum juga mengandungan squalen yang berpotensi mengatasi hiperlipidemia. Squalen dapat menghambat akumulasi lipid oleh sifat hipolipidemianya (Ragasa et al. 2014). Ekstrak dari keseluruhan tanaman lakum dapat memperbaiki gambaran histologi hati tikus yang diinduksi nitrobenzene pada keadaan nekrosis hati dan infiltrasi lipid di hati (Kumar et al. 2011), Ekstrak cair buah kersen dapat memperbaiki profil lemak darah tikus dengan meningkatkan kadar kolesterol HDL sehingga mencegah terbentuknya timbunan lemak di jaringan dan rongga tubuh (Sudargo , 2017), Penumpukan lemak berlebih pada bagian abdominal sering dikaitkan dengan adanya faktor resiko berbagai macam penyakit seperti diabetes militus tipe II, hipertensi, kardiovaskular dan dislipidemia (Klop et al., 2013).

Berdasarkan fakta diatas maka perlu dilakukan penelitian mengenai pengaruh pemberian ekstrak etanol Cayratia trifolia dan buah Muntingia calabura terhadap bobot badan dan bobot lemak abdominal pada Rattus norvegicus sebagai salah satu indikator pengaruh terhadap obesitas.

\section{METODE PENELITIAN}

Alat-alat yang digunakan dalam penelitian ini, yaitu: kandang tikus dengan tutup yang terbuat dari kawat sebanyak 20 buah, botol air minum 20 buah, tempat pemberian pakan 20 buah, sonde, blender, penyaring, beaker glass, timbangan digital, alat bedah, gunting, scalpel, dan pinset, thermometer, higrometer, tabung eppendorf, spuit $3 \mathrm{ml}$, pipet tetes, Cholesterol test Cobalt series, aluminium foil, oven, magnetic hot stirer, tabung reaksi, alat point of care test (POCT), rotary evaporator, sarung tangan dan masker. Bahan- 
bahan yang digunakan dalam penelitian ini, yaitu: tikus putih jantan (Rattus norvegicus L) strain Wistar sebanyak 20 ekor, buah kersen (Muntingia calabura L.), daun tanaman lakum (Cayratia trifolia (L.) Domin.), simvastatin, pelarut etanol, aquades, larutan garam fisiologis $(\mathrm{NaCl})$, alkohol 96\%, alkohol absolut, serum darah tikus, pakan pellet komersial jenis komplit butiran 594 merek peterung, pakan hiperlipidemia tinggi fruktosa, dan sekam padi kering.

Daun lakum yang digunakan dalam penelitian ini diperoleh dari daerah Tanjung Raya 2, Kelurahan Parit Mayor, Kecamatan Pontianak Timur, Kalimantan Barat. Disiapkan daun lakum setengah tua (daun ketiga sampai kelima dari pucuk) sebanyak $800 \mathrm{~g}$ yang sudah bersih kemudian dipotong-potong dan dikeringkan dalam oven pada suhu $40^{\circ} \mathrm{C}$ hingga beratnya konstan. Sampel yang sudah memiliki berat konstan kemudian dimaserasi dengan pelarut etanol 96\% hingga terendam semua selama 2 x 24 jam. Hasil maserasi kemudian disaring, dan hasil penyaringan berupa filtrat kemudian diambil dan diuapkan menggunakan rotary evaporator pada suhu $80^{\circ} \mathrm{C}$. Ekstrak yang diperoleh dari hasil evaporasi berupa pasta. Pembuatan larutan stok ekstrak daun lakum dosis $40 \mathrm{mg} / 200 \mathrm{~g}$ BB dilakukan dengan cara melarutkan 10 gram ekstrak daun lakum ke dalam $50 \mathrm{ml}$ aquades. Setiap pemberian perlakuan ekstrak daun lakum, diambil sebanyak $0,2 \mathrm{ml}$ dari larutan stok..

Buah kersen yang digunakan dalam penelitian ini diperoleh dari desa Kandri, Kelurahan Gunung Pati, Kota Semarang, Jawa Tengah. Buah kersen yang digunakan dalam perlakuan adalah buah yang sudah matang, berwarna merah, dan tidak terdapat cacat/ goresan pada buah. Buah kersen yang sudah dicuci dengan air mengalir kemudian dikeringanginkan dan di buat jus menggunakan blender tanpa penambahan air. Hasil blender yang mengandung buah kersen kemudian disaring dan diambil sarinya.

Pembuatan larutan stok simvastatin dosis $0,18 \mathrm{mg} /$ 200 g BB dilakukan dengan cara menumbuk simvastatin menggunakan lumping dan alu, kemudian ditimbang sebanyak $45 \mathrm{mg}$, dan dilarutkan dalam $50 \mathrm{ml}$ aquades. Setiap pemberian perlakuan simvastatin, diambil sebanyak $0,2 \mathrm{ml}$ dari larutan stok.

Penelitian menggunakan Rancangan Acak Lengkap (RAL) dengan perlakuan pakan sebagai berikut :

$$
\begin{aligned}
& \mathrm{P} 0=\text { kontrol, } \mathrm{P} 1=\text { hiperlipid, } \\
& \mathrm{P} 2=\text { hiperlipid+kersen, } \\
& \mathrm{P} 3=\text { hiperlipid+ekstrak lakum, } \\
& \mathrm{P} 4=\text { hiperlipid+simvastatin. }
\end{aligned}
$$

Tikus perlakuan dikondisikan hiperlipid dengan pemberian pakan hiperlipid selama sebulan. Setelah itu dilakukan pengecekan kadar kolesterol untuk menentukan tikus sudah dalam keadaan hiperlipidemia dengan terlebih dahulu dipuasakan selama 12 jam. Tikus ditimbang 2 kali dalam satu minggu, diukur pemberian pakan dan minum harian.

Di akhir penelittian tikus dilaksanakan diseksi kemudian mengambil bagian lemak abdominal disekitar perut yang terdiri dari lemak retroperitoneal, lemak epididimal dan mesentrika, kemudian ditimbang dengan timbangan organ langsung setelah lemak diperoleh.

\section{HASIL DAN PEMBAHASAN}

Hasil analisis pengaruh pemberian jus buah kersen (Muntingia calabura L) dan ekstrak etanol daun lakum ( Cayratia trifolia L) terhadap konsumsi pakan harian, konsumsi minum harian, dan konversi pakan tikus putih ( Rattus norvegicus) hiperlipidemia dapat dilihat pada Tabel 1.

Hasil perhitungan konsumsi pakan harian Rattus norvegicus pada perlakuan kontrol lebih tinggi dibandingkan pada perlakuan pakan hiperlipid, perlakuan jus buah kersen, perlakuan ekstrak etanol daun lakum, dan simvastatin. Hal ini diduga terjadi akibat adanya simpanan energi dalam makanan yang tinggi yaitu pakan hiperlipid dengan kandungan fruktosa didalamanya. Adanya fruktosa dalam pakan diduga menjadikan sumber energi yang terdapat dalam tubuh meningkat, sehingga keinginan untuk makan menjadi berkurang dan palatabilitas dari tikus yang diberi perlakuan hiperlipidemia menjadi rendah sehingga konsumsi makannya sedikit.

Hasil analisis Anova pengaruh pemberian jus buah kersen (Muntingia calabura) dan ekstrak etanol daun lakum (Cayratia trifolia) terhadap 
konsumsi minum, tikus putih ( Rattus norvegicus) hiperlipidemia menunjukkan hasil yang signifikan. Pakan hiperlipid menurunkan konsusmsi minum dikarenakan pengaruh dari konsumsi makannya yang lebih sedikit dibandingkan perlakuan kontrol. Menurunnya konsumsi minum pada perlakuan dibandingkan kelompok kontrol diduga diakibatkan oleh konsumsi makan yang sedikit sehingga konsumsi minumya juga sedikit. Hal ini diperkuat pendapat dari Smith dan Mangkoewidjojo (1988) mengungkapkan bahwa kebutuhan minum seekor tikus setiap hari kira-kira 15-30 ml air. Jumlah ini dapat berkurang jika pakan yang dikonsumsi sudah banyak mengandung air.

Tabel 1. Hasil Analisis Konsumsi Pakan, Konsumsi minum dan Konversi Pakan

\begin{tabular}{|c|c|c|c|c|c|}
\hline \multirow[t]{2}{*}{ Parameter } & \multicolumn{5}{|c|}{ Perlakuan } \\
\hline & $\mathrm{P} 0$ & P1 & P2 & P3 & P4 \\
\hline Konsumsi & $15,80^{\mathrm{b}} \pm 0,48$ & $11,57^{\mathrm{a}} \pm 0,47$ & $11,07^{\mathrm{a}} \pm 1,14$ & $10,92^{\mathrm{a}} \pm 0,49$ & $10,52^{a} \pm 1,53$ \\
\hline $\begin{array}{l}\text { Konsumsi } \\
\text { Minum Harian }\end{array}$ & $25,20^{\mathrm{b}} \pm 1,08$ & $21,57^{\mathrm{a}} \pm 1,43$ & $20,07^{\mathrm{a}} \pm 1,56$ & $20,95^{\mathrm{a}} \pm 1,03$ & $20,72^{a} \pm 3,14$ \\
\hline $\begin{array}{l}\text { Konversi } \\
\text { Pakan }\end{array}$ & $\begin{array}{c}0,059^{\mathrm{b}} \\
0.004\end{array}$ & $\begin{array}{c}0,046^{\mathrm{a}} \pm \\
0,002\end{array}$ & $\begin{array}{c}0,047^{\mathrm{a}} \\
0,002\end{array}$ & $\begin{array}{c}0,046^{\mathrm{a}} \pm \\
0,004\end{array}$ & $\begin{array}{c}0,050^{\mathrm{a}} \pm \\
0,004\end{array}$ \\
\hline hip & kstrak daun & $\begin{array}{l}\text { hiperli } \\
\text { P4= per } \\
\text { SD }\end{array}$ & bemberi & . & erlin \\
\hline
\end{tabular}

Disisi lain Lozano (2016) berpendapat bahwa konsumsi minum dan melumasi sendi agar tetap lentur. Dari pendapat diatas jelas bahwa konsumsi minum pada tikus salah satunya untuk memberikan energi, sedangkan energi yang di butuhkan untuk perlakuan pakan tinggi lemak yang mengandung fruktosa telah mensuplai energi lebih besar dibandingkan pakan standar sehingga menyebabkan konsumsi minumnya sedikit.

Hasil uji Anova pengaruh pemberian jus buah kersen (Muntingia calabura) dan ekstrak etanol daun lakum (Cayratia trifolia) terhadap konversi pakan, tikus putih (Rattus norvegicus) hiperlipidemia menunjukkan hasil signifikan. Kelompok P1, P2, P3, dan P4 memiliki nilai konversi pakan yang rendah dan tidak berbeda nyata satu sama lain. Nilai konversi pakan tertinggi terdapat pada pakan kelompok kontrol 0,059. Rendahnya nilai konversi pakan beberapa perlakuan dikarenakan adanya efisiensi pakan yang baik pada hewan coba. Hal ini sesuai dengan pendapat Willems et al. (2013) menyatakan bahwa rendahnya angka konversi pakan menunjukkan adanya keberhasilan pemeliharaan hewan coba dalam efisiensi pencernaan makanan . Konversi pakan yang rendah pada perlakuan hiperlipid diduga karena pemberian pakan hiperlipid meningkatkan efisisensi pakan, peningkatan efisiensi diduga karena adanya fruktosa dalam pakan yang tinggi. Hal tersebut diperkuat oleh Murray et al (2003) yang menyatakan bahwa kandungan fruktosa dapat bermanfaat dalam efisiensi pemberian makan pada hewan coba, karena menekan keinginan makan karena mengandung banyak sumber energy yang dibutuhkan oleh tubuh. Senyawa flavonoid yang terdapat dalam pemberian perlakuan jus buah kersen dan ekstrak daun lakum turut diduga menjadi faktor penurun konversi pakan karena mampu berperan dalam membunuh mikrorganaisme patogen. Hal ini sesuai dengan pendapat dari Shabella (2013) yang menyatakan bahwa senyawa aktif flavonoid juga berperan sebagai antibiotik dengan mengganggu fungsi dari mikroorganisme patogen seperti bakteri dan virus. Flavonoid memiliki kemampuan untuk membentuk struktur kompleks berikatan dengan protein ekstraseluler dan akan merusak dinding sel mikroba karena sifatnya yang lipofilik. Aktivitas fitofarmaka dari flavonoid adalah sebagai anti inflamasi, 
analgesik, dan antioksidan. Table 1. menunjukkan adanya keterkaitan antara konsumsi makan dengan konversi pakan, semakin besar konsumsi makannya maka semakin besar pula konversi pakannya. Kebutuhan makan tikus dalam kesehariannya ratarata $9-13 \%$ dari bobot tubuhnya. Hal ini sesuai dengan pendapat dari Smith dan Mangkoewidjojo (1988) bahwa kebutuhan pakan bagi seekor tikus setiap harinya kurang lebih sebanyak $10 \%$ dari bobot tubuhnya jika pakan tersebut berupa pakan kering dan dapat ditingkatkan sampai $15 \%$ dari bobot tubuhnya jika pakan yang dikonsumsi berupa pakan basah

Hasil analisis pengaruh pemberian jus buah kersen (Muntingia calabura L) dan ekstrak etanol daun lakum ( Cayratia trifolia L) terhadap bobot badan dan bobot lemak abdominal tikus putih ( Rattus norvegicus L) hiperlipidemia dapat dilihat pada Tabel 2.

Tabel 2. Hasil Analisis Data Bobot Badan dan Bobot Lemak Abdominal

\begin{tabular}{lcllll}
\hline Parameter & \multicolumn{4}{c}{ Perlakuan } \\
\cline { 2 - 6 } & P0 & P1 & P2 & P3 & P4 \\
\hline Bobot Badan & $294,15^{\mathrm{c}} \pm$ & $251,98^{\mathrm{b}} \pm 20,86$ & $223,22^{\mathrm{ab}} \pm 18,8$ & $227,28^{\mathrm{ab}} \pm 26,18$ & $208,55^{\mathrm{a}} \pm 24,21$ \\
& 21,6 & & & & \\
Bobot Lemak & $4,97^{\mathrm{ab}} \pm 3,12$ & $6,22^{\mathrm{b}} \pm 3,38$ & $1,63^{\mathrm{a}} \pm 0,82$ & $2,77^{\mathrm{ab}} \pm 0,92$ & $1,75^{\mathrm{a}} \pm 1,15$ \\
Abdominal & & & & & \\
\hline
\end{tabular}

Keterangan: Superskrip yang berbeda pada baris yang sama menunjukkan berbeda nyata $(\mathrm{p}<0,05) . \mathrm{P} 0=$ perlakuan kontrol pemberian pakan standar, $\mathrm{P} 1=$ perlakuan pemberian pakan hiperlipid, $\mathrm{P} 2=$ perlakuan pemberian pakan hiperlipid+buah kersen, $\mathrm{P} 3=$ perlakuan pemberian pakan hiperlipid+ekstrak daun lakum, P4= perlakuan pemberian pakan hiperlipid+simvastatin. Data yang ditampilkan berupa ratarata \pm SD

Hasil analisis dengan Anova pengaruh pemberian jus buah kersen (Muntingia calabura) dan ekstrak etanol daun lakum (Cayratia trifolia) terhadap bobot badan tikus putih ( Rattus norvegicus) hiperlipidemia (Tabel 2) menunjukkan hasil yang signifikan. Hal ini dikarenakan terdapat banyak faktor, dalam penelitian ini, faktor yang paling berpengaruh adalah konsumsi pakan. Hal tersebut sesuai dengan pendapat dari Sudargo (2017) yang menyatakan bahwa bobot badan sangat dipengaruhi oleh pola konsumsi makan, minum, stress, aktivitas dan kesehatan.

Kelompok tikus yang diberikan pakan standar (P0) menunjukkan hasil bobot badan paling tiggi dibandingkan dengan perlakuan lainnya. Salah satu faktor penyebabnya yaitu dengan komposisi pakan yang tersusun atas kadar air 13\%, Protein $18,5 \%$, Lemak 6,09\%, Serat Kasar 6,08\%, Abu $8 \%$, kalsium $0,9 \%$ dan phospor $0,7 \%$. Hal ini diduga diakibatkan oleh adanya kandungan lemak, serat kasar, protein, dan kalsium yang berfungsi sebagai nutrisi dalam tubuh untuk proses metabolisme sel. Peningkatan bobot badan diduga karena hasil metabolisme digunakan untuk menyusun struktural tubuh seperti otot, massa tulang dan lain lain. Berdasarkan data Tabel 4.1 rata-rata konsumsi pakan harian sebesar 15,80 g sehingga berpengaruh signifikan terhadap bobot badan. Hal ini sesuai dengan pendapat dari Lewis (2005) yang menyatakan bahwa konsumsi yang tinggi pada hewan coba dapat menunjang peningkatan berat badan, massa otot, massa tulang dan panjang tubuh.

Pakan hiperlipidemia diduga tidak terlalu mudah dicerna karena mengandung berbagai macam zat seperti kasein, fruktosa, dan minyak padat. Selain hal tersebut kebutuhan energi dari pakan hiperlipidemia menyuplai tubuh tikus dengan sangat baik, sehingga keinginan makan akan berkurang, berbeda dengan model pakan kelompok kontrol. Hal tersebut sesuai dengan pendapat dari Colville dan Basert (2008) yang menyatakan bahwa konsumsi pakan pada hewan uji digunakan untuk memenuhi kebutuhan energi untuk keperluan metabolisme sel-sel tubuh. Konsumsi dipengaruhi oleh kesediaan energi dalam tubuh, ketika tubuh kekurangan energi naluri untuk makan dari hewan uji meningkat. 
Bobot badan antara P1 dengan P4 menunjukkan adanya perbedaan nyata diantara dua perlakuan tersebut. Hal ini menunjukkan bahwa pemberian simvastatin dapat menurunkan bobot badan tikus hiperlipidemia. Simvastatin sendiri adalah obat yang umum yang beradar di pasaran. Obat Simvastatin telah teruji klinis dengan beberapa perkembangan. Simvastatin diduga menjadi penyebab penurunan bobot badan pada kelompok perlakuan P4 karena mampu menghambat proses-proses metbolisme didalam hati. Hal ini sesuai dengan pendapat dari Stringer (2008) mengungkapkan pemberian simvastatin pada kelompok perlakuan juga dapat meningkatkan kadar HDL tikus hiperlipidemia. Simvastatin merupakan golongan statin. Cara kerja statin sebagai penghambat HMG-CoA reductase yaitu menghambat sintesis kolesterol di hati dan mengakibatkan penurunan kadar LDL plasma. Penghambat reduktase menginduksi suatu peningkatan reseptor LDL dengan afinitas tinggi. Efek tersebut meningkatkan baik kecepatan katabolisme fraksional LDL maupun eksiksi prekursor LDL oleh hati, sehingga mengurangi simpanan LDL plasma. Penurunan trigliserida plasma dan peningkatan kadar kolesterol HDL terjadi selama pengobatan. Hal tersebut diperkuat dengan pendapat dari Sulistia (2005) bahwa penurunan trigliserida plasma dapat mengurangi jumlah kilomikron yang akan diangkut darah melalui ductus toraksikus. Hidrolisis kilomikron dan trigliserida oleh lipoprotein lipase menjadi berkurang. Akibatnya asam lemak bebas dan kilomikron yang akan menembus endotel dan jaringan lemak menjadi sedikit. Sehingga tidak terdapat banyak simpanan lemak di jaringan tubuh, yang menyebabkan bobot tubuh berkurang. Pada perlakuan P1 bobot badan lebih tinggi dibandingkan P4 dikarenakan pemberian pakan tinggi lemak, hal tersebut dikarenakan pakan tinggi lemak diduga meningkatkan kinerja beberapa enzim didalam tubuh yang mendukung proses metabolisme lemak. Hal ini sesuai dengan pendapat Lewis (2005) yang menyatakan bahwa mengungkapkan bahwa pemberian pakan tinggi lemak dapat meningkatkan aktifitas dari hepatik lipase, yang merupakan enzim lipolitik yang disintesis oleh sel hepatosit, peningkatan aktivitas hepatik lipase pada tikus dapat berakibat pada pengurangan kadar HDL serta memperkecil ukuran HDL sehingga proses degradasi kolesterol berkurang termasuk di dalamnya kadar trigliserida yang akan ditimbun dalam jaringan menjadi berlebih, yang menyebabkan bobot badan menjadi bertambah

Hasil analisis dengan Anova pengaruh pemberian jus buah kersen (Muntingia calabura) dan ekstrak etanol daun lakum (Cayratia trifolia) terhadap bobot lemak abdominal tikus putih (Rattus norvegicus) hiperlipidemia (Tabel 4.2) menunjukkan hasil yang signifikan. Hasil Uji Duncan menunjukkan berbeda nyata antara P1 dengan P2, P1 dengan P4, namun tidak terjadi perbedaan nyata antara $\mathrm{P} 1$ dengan $\mathrm{P} 0, \mathrm{P} 1$ dengan P3, P2 dengan P3, P3 dengan P4.

Bobot lemak abdominal pada pada tikus kontrol (P0) tidak signifikan dengan tikus hiperlipidemia (P1). Hal ini menunjukkan bahwa penimbunan kelebihan energi pada tikus hiperlipidemia yang disimpan dalam bentuk trigliserida sebagai lemak abdominal masih dalam batas normal. Kelompok tikus perlakuan pemberian pakan hiperlipid kemudian diberikan jus buah kersen (P2) menunjukan hasil pengaruh yang signifikan dibandingkan kelompok P1 hiperlipid dengan rata-rata bobot lemak abdominal 1,63 g. Pemberian jus buah kersen pada tikus hiperlipidemia dapat menurunkan timbunan lemak abdominal. Hal ini diduga terdapat senyawa bioaktif, dan antioksidan seperti squalene, flavonoid, alkaloid, saponin, tannin, fenol dan asam askorbat. Perlakuan pemberian jus buah kersen bertujuan untuk menambah asupan antioksidan dalam tubuh tikus melalui kandungan senyawa squalen dan flavonoid yang terdapat dalam jus tersebut, diperkirakan kandungan senyawa tersebut terserap dengan baik dan mampu mensuplai antioksidan eksogen yang dibutuhkan oleh tikus.

Rabeta and Lin (2015) mengungkapkan kandungan flavonoid dan trapenoid buah kersen dianggap sebagai salah satu faktor pembentukan serta perbaikan sel di tingkat mitokondria. Perbaikan sel tersebut mendorong respirasi mitokondria menjadi lebih lancar, akibatnya daur energi dalam tingkat sel kembali berjalan. Sehingga timbunan lemak dalam bentuk trigliserida dan asam 
lemak dalam jaringan berkurang karena digunakan sebagai sumber energi. Beberapa golongan senyawa yang dapat berperan sebagai antioksidan adalah flavonoid, fenolik dan triterpenoid. Golongan senyawa flavonoid dan fenolik dapat berikatan dengan radikal bebas sehingga mengembalikan fungsi dari mitokondria dan glutation (GSH) seluler. Hal tersebut juga sesuai dengan penelitian Preethi et al., (2012) Ekstrak dari buah kersen memiliki aktivitas antioksidan dan anti inflamasi yang dapat berfungsi mensuplai kebutuhan antioksidan eksogen yang diperlukan oleh tubuh untuk proses metabolisme seluler. Ragasa et al. (2015) juga mengamati adanya kandungan squalene, trigliserida, sitosterol, stigmasterol dan asam lemak pada ekstrak kering buah kersen.

Perlakuan tikus hiperlipidemia dan diberi ekstrak daun lakum (antara P1 dengan P3) tidak berbeda nyata, hal tersebut diduga dikarenakan terjadi perbedaan penyerapan dalam usus halus Rattus norvegicus, kandungan senyawa pada buah kersen dan ekstrak etanol daun lakum berbeda dalam jumlah total kandungannya. Hasil analisis penelitian mengenai senyawa pada kersen oleh Preethi et al (2012) dan senyawa ekstrak daun lakum oleh Sundaram et al. 2015 terdapat perbedaan kandungan flavonoid dan fenol. Buah kersen memiliki total kandungan flavonoid dalam $100 \mathrm{~g}$ berat sebesar $300 \mathrm{mg}$, sedangkan ekstrak etanol daun lakum hanya sebesar 60,4 mg. Kandungan fenol dari buah kersen mencapai 1491 $\mathrm{mg} / 100 \mathrm{~g}$ berat segar sedangkan pada ekstrak etanol daun lakum hanya memiliki kandungan fenol sebesar 80,1 mg. Hal tersebut diperkuat dari pendapat dari Roat dan Saraf (2017) yang mengungkapkan bahwa pada Cayratia trifolia terdapat senyawa bioaktif yang berguna dalam penurunan kolesterol, seperti fenol, flavonoid, tannin, saponin, dan alkaloid. Semua senyawa dapat efektif diambil dari tumbuhan melalui proses ekstraksi dengan pelarut etanol. Tetapi dalam proses pengambillan senyawa tersebut harus memerhatikan prosedur yang tepat, teknik aseptik, dan penyimpaan yang benar.

Perlakuan hiperlipidemia (P1) dengan perlakuan pemberian simvastatin (P4) menunjukan adanya beda yang nyata. Pemberian simvastatin merupakan obat penurun kolesterol yang sangat umum digunakan karena telah melalui serangkaian uji klinis mencari formula yang tepat dan terus dikembangkan . Simvastatin akan menghambat dari kinerja HMG Co-A-reduktase yang akan mensintesis lemak. Stringer (2008) dalam penelitianya mengungkapkan pemberian simvastatin pada kelompok perlakuan juga dapat meningkatkan kadar HDL tikus hiperlipidemia. Simvastatin merupakan golongan statin. Cara kerja statin sebagai penghambat HMG-CoA reductase yaitu menghambat sintesis kolesterol di hati dan mengakibatkan penurunan kadar LDL plasma. Penghambat reduktase menginduksi suatu peningkatan reseptor LDL dengan afinitas tinggi. Efek tersebut meningkatkan baik kecepatan katabolisme fraksional LDL maupun eksiksi prekursor LDL oleh hati, sehingga mengurangi simpanan LDL plasma.

Penurunan trigliserida plasma dan peningkatan kadar kolesterol HDL terjadi selama pengobatan. Penurunan LDL plasma ini akan mengurangi kilomikron dan trigliserida yang beradar melalui darah. Sedangkan pada perlakuan pemberian pakan hiperlipid terjadi peningkatan aktivitas metabolisme dalam ubuh karena kelebihan energi. Energi yang belum terpakai di duga disimpan dalam bentuk lemak salah satunya di daerah abdominal. Hal tersebut didukung pendapat dari Hardiningsih dan Nurhidayat (2006) menyatakan bahwa pakan tinggi kolesterol meningkatkan aktifitas lipoprotein lipase yang diseintesis di dalam hati oleh sel hepatosit, menyebabkan kadar HDL berkurang, dan meningkatkan kadar LDL.

Proses degradasi kolesterol berkurang termasuk di dalamnya kadar trigliserida karena HDL yang sedikit. Beberapa trigliserida dan asam lemak yang diangkut dalam bentuk kilomikron tersebar menuju ke bagian bagian tubuh yang kemudian terakumulasi, salah satunya bagian abdominal. Maigoda et al. (2016) turut menjelaskan bahwa pakan tinggi lemak menyebabkan peningkatan berat organ hati disertai peningkatan berat lemak intra-abdominal di rongga perut tikus. 


\section{KESIMPULAN}

Berdasarkan penelitian yang telah dilakukan dapat disimpulkan bahwa pemberian jus buah kersen (Muntingia calabura) dan ekstrak etanol daun lakum (Cayratia trifolia) selama 4 minggu tidak berpotensi menurunkan bobot badan, namun berpotensi menurunkan bobot lemak abdominal.

\section{UCAPAN TERIMA KASIH}

Penulis mengucapkan terima kasih kepada Fakultas Sains dan Matematika Universitas Diponegoro atas bantuan nya melalui dana Penerimaan Negara Bukan Pajak (PNBP)

\section{DAFTAR PUSTAKA}

Colville, T. and J.M. Bassert, 2008. Clinical Anatomy and Physiology for Veterinary Technicians. 2nd Edition. Mosby Elsevier. United Kingdom.

Guyton, A.C. dan Hall, J.E. 1997. Buku Ajar Fisiologi Kedokteran. Edisi ke9. Editor Bahasa Indonesia: Irawati Setiawan. Jakarta: ECG. pp: 1077.

Handajani, S. 2006. The queen of seeds : Potensi agribisnis komoditas Wijen, Andi offset. Yogyakarta.

Hardiningsih R. dan Nurhidayat N. 2006. Pengaruh pemberian pakan hiperkolesterolemia terhadap bobot badan tikus putih wistar yang diberi bakteri asam laktat. Biodiversitas. 7(2):127-130.

Hazleman, B., Riley, G., and Speed, C. (2004). Soft tissue rheumatology Oxford: Oxford University Press.

Kementrian Kesehatan Republik Indonesia. Riset Kesehatan Dasar Tahun 2013. Jakarta: Badan Penelitian dan Pengembangan Kesehatan Kementrian Kesehatan RI; 2013.

Klop, B., Elte J.W.F., and Cabezas M.C. 2013. Dyslipidemia in obesity : mechanism and potential targets. Nutrients. 5:1218-1240.
Kumar, G. Arya, R. and Kumar, T. 2011. Hepatoprotective Activity of Cayratia trifolia (L.)Domin Against Nitrobenzene Induced Hepatotoxicity. Latin American Journal of Pharmacy. 30 (3): 546-9.

Lewis, G F. Daniel J. Rader, 2005, New Insights Into the Regulation of HDL Metabolism and Reverse Cholesterol Transport, Circulation Research, $96: 1226$.

Lozano .2016. High-fructose and high-fat dietinduced disorders in rats: impact on diabetes risk, hepatic and vascular complications. Nutrition \& Metabolism, 13:15.

Maigoda TC, Sulaeman A, Setiawan B, Wibawan IWT. 2016. Effects of red dragon fruits (Hylocereus polyrhizus) powder and swimming exercise on inflammation, oxidative stress markers, and physical fitness in male obesity rats (Sprague dawley). IJSBAR 25(1):123-141.

Murray, R.K., Granner, D.K., Mayes, P.A. dan Rodwell, V.W. 2003. Biokimia Harper. Edisi 25. Penerbit Buku Kedokteran EGC. Hal : 276 - 283. Jakarta

Preethi, K., P. Premasudha, and K. Keerthana. 2012. Anti-inflammatory activity of Muntingia calabura fruits. Pharmacognosy Journal. 4 (30): $51-56$

Rabeta, M.S. dan Lin, S.P. 2015. Effects of Different Drying Methods on the Antioxidant Activities of Leaves and Berries of Cayratia trifolia. Sains Malaysiana. 44(2):275-280.

Ragasa, C.Y, Buluran, A.I, Mandia, E.H and Shen, C.C. 2014. Chemical constituents of Cayratia trifolia. Der Pharma Chemica. 6 (6): 418-422.

Ragasa, C.Y., Buluran, A.I, Mandia, E.H and Shen, C.C., 2015. Chemical constituents of Muntingia calabura L.. Der Pharma Chemica. 7(5): 136-141.

Roat, C., dan M. Saraf. 2017. Isolation and Screening of Resveratrol Producing Endphytes from Wild Grape Cayratia trifolia. International Journal of Advances 
in Agricultural Science and Technology. 4(11).

Rolfes, S.R., Pinna, K., and Whitney, E. 2009. Understanding Negatif and Clinical Nutrition Eight Edition. Belmonth (CA). Wadsworth. Cengange Learning.

Schoettl, T., Fischer, I.P., and Ussar, S. 2018. Heterogeneity of adipose tissue in development and metabolic function. Journal of Experimental Biology. 221: jeb162958 doi: 10.1242/jeb.162958.

Shabella, R. 2013. Terapi Daun Binahong. Cetakan 1. Cable Book, Jakarta.

Stringer JL.,2008, Obat-obat Penurun Lipid Konsep Dasar Farmakologi: Panduan untuk Mahasiswa, Edisi 3, EGC, Jakarta.

Sudargo, T. 2017. The effect of kersen juice on lipid profile of Spargue Dawley rats: a randomized controlled trial. Asian Journal of Clinical Nutrition. 9 (3): $97-$ 103.

Sundaram, S., Perumal, P.C., Palanirajan, A., and Balu,V. 2015a. In vitro antioxidant activity, in vivo skin irritation studies and HPTLC analysis of Cayratia trifolia (L.) Domin. International Journal of Toxicological and Pharmacological Research. 7 (1): 1-9.

Smith, J.B. dan S. Mangkoewidjojo. 1988. Pemeliharaan, Pembiakan Dan Penggunaan Hewan Percobaan Di Daerah Tropis. UI Press. hlm. 3757. Jakarta.

Sulistia G.G. 2005. Farmakologi dan Terapi. Edisi 4. Bagian Farmakologi Fakultas Kedokteran Universitas Indonesia. Gaya Baru. pp: 427-8, 364-5. Jakarta.

Willems, O. W., S. P. Miller and B. J. Wood. 2013. Aspects of Selection for Feed Efficiency in Meat Producing Poultry. World's Poultry Science Journal, 69 (1): 77-88 